\title{
The effect of demographic factors on behavioral biases
}

\author{
Vania Beatrice, Werner R. Murhadi ${ }^{*}$, Arif Herlambang \\ Faculty of Business \& Economics, University of Surabaya, Surabaya, Indonesia \\ *Corresponding author: werner@staff.ubaya.ac.id
}

\begin{abstract}
The purpose of this study was to examine the influence of demographic factors such as gender, age, education, occupation, income, and investment experience on investor behavior bias such as overconfidence bias, disposition effects, herding bias, and mental accounting. This type of research was causal research with a quantitative approach, and the analytical method used was the analysis of SEM (structural equation modeling). This research was conducted by distributing questionnaires to investors listed on the Indonesia Stock Exchange with a minimum age of 17 years. The results showed that overconfidence bias was influenced by investment experience while disposition effect was influenced by age, income level, and investment experience. Herding bias was influenced by age and occupation while mental accounting was influenced by income level.
\end{abstract}

Keywords: Behavioral Finance, overconfidence bias, disposition effect, herding bias, mental accounting JEL Classification Code: G24, G40, G41 DOI: 10.20885/jsb.vol25.iss1.art2

\section{Introduction}

Investment is an activity to prepare future needs by utilizing the funds owned. An investor hopes to get a return or capital gain from the investment. In investing, an investor will recognize the risk and the expected rate of return. Many things can influence making a decision in investing, one of which is behavioral finance. There are times when investors are less rational in making investment decisions because they involve psychological aspects that result in deviations from irrational investor behavior and making decision bias. Financial behavior, namely studying how humans behave in a financial-related decision and studying psychological factors will influence financial decision making, companies, and financial markets (Nofsinger, 2001). One of the phenomena in Indonesia is that many investors in investing in stocks pay attention to the right sources of information. Recommendations from securities or forums also help investors to make a decision. The problem is that many investors do not refer to valid information. Investors buy shares because of rumors, sell because "people say" the shares are wrong. Recommendations from forums and the results of securities analysis do not necessarily provide valid recommendations; they can even lure investors into buying shares so that stock prices rise and those who recommend selling make profits. This invalid and irresponsible information can influence investors to tend to make biased decisions. Apart from that, demographic factors such as gender, age, education level, income level, marital status, occupation, and investment experience also influence investment decision making.

Baker et al. (2018) conducted a study to examine the effect of financial literacy and demographic variables (gender, age, education level, occupation, marital status, and investment experience) related to bias behavior. The results showed different biased behavior, including overconfidence and self-attribution, the disposition effect, anchoring bias, representativeness, mental accounting, emotional biases, and herding. Therefore, these findings support the view that investors do not always act rationally in making investment decisions. Age, occupation, and investment experience are the most important demographic variables associated with individual investors' discriminatory behavior. Men are more confident than a woman when compared to women about knowledge in the stock market. It is similar to previous research conducted by 
Lewellen et al. (1977), Barber and Odean (2001), Bhandari and Deaves (2006), Lin (2011), and Kumar and Goyal (2016). Baker et al. (2018) also found that young investors will tend to make safe investments related to their returns. Another study conducted by Kumar and Goyal (2016) investigated the relationship between rational decision-making and investor behavior in India and examined the effect of demographic variables on the decision-making process and bias behavior. The results showed that investors follow a rational decision-making process when investing, and behavioral bias also affects the decision-making process. Gender and income have significant differences concerning rational decision making. Male investors are more prone to overconfidence and herding bias in India. Based on limited information and personal information, men tend to be more confident. This research is the same as research conducted by Barber and Odean (2001), Bhandari and Deaves (2006), and Lin (2011). In terms of herding bias during the search for investment information, men tend to follow other investors, such as friends and relatives.

A similar study conducted by Prosad et al. (2015) aimed to examine bias behavior among Indian investors, particularly on bias overconfidence, excessive optimism (pessimism), herd behavior, and disposition effects. The results showed that the most influencing factors were age, occupation, and trafficking frequency against these four biases. Prosad et al. (2015) found that male investors are more confident than women regarding the knowledge they have regarding India's stock market. Women feel less confident and pessimistic than men because women think that the price of gold will improve soon, so that women are more interested in investing in gold than investing in the Indian stock market. Isidore \& Christie's (2018) examined the relationship between the level of annual income earned by investors in Chennai, India, and the behavioral bias shown by investors, namely mental accounting, anchoring, gambler's fallacy, availability, loss aversion, regret aversion, representativeness, and overconfidence. This test showed that investors who have higher income levels are less likely to be biased than investors who have lower income level. Investors who have higher income levels tend to show overconfidence bias and low mental bias in accounting, availability, loss aversion, regret aversion, and representativeness.

This study discussed the demographic factors that affect behavioral bias, namely overconfidence, disposition effect, herding, and mental accounting, in making investment decisions (Baker et al. (2018). This study focused on investors who invest in stock investment products in Indonesia. This study produced findings of the influence of demographic factors on the bias of investor behavior in making investment decisions on stocks.

\section{Literature Review and Hypotheses}

Behavioral finance or behavioral finance describes insights from psychology, finance, and other sciences to study behavior in various market settings that deviate from standard assumptions (Yoong and Ferreira, 2013). According to Hirshleifer et al. (1998), investors are susceptible to various behavioral biases, which become an obstacle to maximizing investors' wealth. Irrational valuations in investments are known as illusions or biases. Kahneman and Riepe (1998) 's views on behavioral bias need to be understood to avoid mistakes in reasoning or judgment in making an investment decision. Investor behavior in making investment decisions is influenced by behavioral bias due to limited rationality so that decisions tend to be irrational (Byrne and Brooks, 2008). According to Phung (in Isidore \& Christie, 2018), in decisions when investing, investors will play their emotions, which are very important as information and high uncertainty to direct learning to investigate psychology to explain investor behavior. According to Kahneman and Tversky (1979), developing a prospect theory for decision making under uncertainty is a critique of expected utility theory. Prospect theory believes that several psychological factors influence investors' decisions and deviations from rationality. These psychological factors are known as behavioral bias and will cause

a decrease in the return on investment. According to Pompian (2006), the behavioral bias in investing consists of two categories, namely Cognitive Bias and Emotional Bias. 
According to Pompian (2006), a cognitive bias is a process deviation in understanding, managing, and making decisions on information or facts received. This bias describes any irregularities or errors that occur with information held by investors. Those included in cognitive bias are representative bias, anchoring \& adjustment bias, availability bias, self-attribution bias, an illusion of control bias, conservatism bias, confirmation bias (selection bias), hindsight bias, mental accounting, herding bias, and the disposition effect. Meanwhile, emotional bias tends to involve feelings and spontaneity rather than involving facts or information (Pompian, 2006). Emotional bias will describe errors in deciding because they ignore facts. Emotional bias includes overconfidence bias, loss aversion bias, self-control bias, status-quo bias, endowment bias, regret-aversion bias, and greed bias. The research will focus more on the reference journal used; according to Baker et al. (2018), the behavioral bias that will consist of 4 parts, namely: (1) overconfidence; (2) disposition effect; (3) herding, and; (4) mental accounting. Furthermore, below is presented a summary of the development of the research hypothesis.

Baker et al. (2018) found that female investors tend to be less confident than male investors. Supported by other research such as Barber and Odean (2001), Bhandari and Deaves (2006), Lin (2011), and Kumar and Goyal (2016) showed that male investors will be more confident than women. Female investors will tend to be more afraid to take risks, which affects women's level of confidence when making investment decisions.

H1a: Gender has a negative effect on overconfidence bias.

Kaustia (2010) stated that disposition effect is a phenomenon where investors tend to realize or sell profits and are reluctant to lose by holding bad stocks. According to the research by Baker et al. (2018), the gender of female investors has more disposition effect than male investors. After experiencing the benefits of previous investments, female investors are more likely to invest more.

H1b: Gender has a positive influence on the disposition effect.

Herding bias tends for investors to make investment decisions to follow the crowd (Prosad et al., 2015). Research conducted by Nair et al. (2017) found that female investors are more likely to have a herding bias than male investors. Research by Lin (2011) also found that women are more likely to have a herding bias than men. Male investors are more assertive in making investment decisions than female investors who are more comfortable to follow the ideas of those around them (Feingold, 1994).

H1c: Gender has a positive influence on the herding bias.

Thaler (1999) viewed that mental accounting is a bias that showed investors to regulate, evaluate, and track financial activities. According to Thaler (1999), mental accounting consists of three elements: Photographing how the results of decisions are made and evaluated; Grouping into several accounts of each activity; and, the frequency of each account being evaluated. According to Baker et al. (2018), male investors are more likely to show mental accounting than female investors. Female investors are less likely to show mental accounting towards the reference category. Furnham (1984) argued that women and men have different views on money. Men are more obsessed with money, and women are more conservative in their finances.

H1d: Gender has a positive influence on the mental accounting

According to Pompian (2006), this bias tends to be where investors take an investment decision because of excessive confidence in predictions and information. Investors have unwarranted beliefs in terms of intelligence, abilities, and judgment. Research results from Prosad et al. (2015) showed that investors aged 51-60 years old or above have a high level of confidence 
when compared to the middle to lower age. Investors who are 51-60 years old are believed to have a broad knowledge and understanding of investing compared to other ages.

H2a: Age has a positive influence on overconfidence bias.

Fogel and Berry (2006) stated that the disposition effect shows investors want to avoid regret or risk because the decisions taken are the wrong decisions. Research from Kumar and Goyal (2016) showed that young and middle-aged investors 25-45 years have a more disposition effect than older investors. Young investors often have less experience than older investors. With a little experience, young investors are often reluctant to realize the disadvantages of their portfolios.

$\mathrm{H} 2 \mathrm{~b}$ : Age has a negative influence on disposition effect

According to Kumar and Goyal (2016), herding refers more to investors' tendency to imitate the valuation of an investment with other people. Research by Baker et al. (2018) stated that older investors are less likely to show a herding bias. Young investors tend to have a herding bias due to a lack of information and a lack of understanding and knowledge. Due to these lacks, investment decisions will follow investors.

$\mathrm{H} 2 \mathrm{c}$ : Age has a negative influence on herding bias

According to Thaler and Shefrin (1981), mental accounting is defined as the behavior of investors who separate every outgoing and incoming fund like an accounting model. The basis of mental accounting is the placement of investment assets into different "buckets" according to the type of asset regardless of the correlation that links investments in various categories. Research conducted by Baker et al. (2018) showed that older investors are more likely to be mentally accounting than younger investors. Age 46 years and over will tend to have mental accounting. Older investors will be influenced by mental accounting bias to build their portfolios (Essayyad and Desai, 2008)

$\mathrm{H} 2 \mathrm{~d}$ : Age has a positive influence on mental accounting.

Barber and Odean (2001) found that investors who show excessive self-confidence lead to poor performance and excessive trading. Investors having a high level of education will influence behavioral bias, and the higher the level of education, the more self-confidence will be (Goo et al., 2010). Investors who have a higher level of education will be more confident and trust the results of their investment decisions because they feel they have more knowledge (Bhandari and Deaves, 2006). H3a: Education level has a positive effect on overconfidence bias.

Kaustia (2010) stated that disposition effect is a phenomenon where investors tend to realize or sell profits and are reluctant to lose by holding bad stocks. Baker et al. (2018) stated that investors who have undergraduate and postgraduate education have a lower disposition effect than investors with low education, supported by Dhar and Zhu's (2006) research. According to Alexander et al. (1997), investors who graduated from undergraduate have more knowledge about financial investment, the lower it is to have a bias disposition effect.

H3b: Education level has a negative effect on disposition effect.

Fernandez et al. (2011) stated that there is an interdependent relationship between available information and group behavior. If investors find uncertain information, investors will imitate decisions with other people or groups. Investors who have a high level of education will have sufficient knowledge of financial literacy. The higher the level of education, the more selfconfidence results from their own investment decisions, and they do not tend to follow other people's information or investment decisions (Goo et al., 2010).

H3c: Education level has a negative effect on herding bias. 
In mental accounting as a process formulated by people's behavioral and emotional factors, the previously codded data in the human brain are used in making a financial decision. All individuals can make a right or wrong decision on financial issues due to signals formulated in their brains. A logical or rational decision can follow this trend (Nuriyev \& Azizov, 2020). The research of Baker et al. (2018) showed that investors who have higher education levels, such as postgraduate degrees, tend to have less mental accounting than lower levels of education.

H3d: Education level has a negative effect on mental accounting.

According to Hirshleifer et al. (1998), investors will tend to ignore signals about information and only follow their self-confidence. Baker et al. (2018) found that retired investors are more confident than private-sector employees. According to Chandra et al. (2015), investors who work in the financial sector will be confident in making investment decisions.

H4a: Occupation has a positive influence on overconfidence bias.

Fogel and Berry (2006) stated that the disposition effect shows investors want to avoid regret or risk because the decisions taken are the wrong decisions. According to Dhar and Zhu (2006), regarding the bias of investor behavior in the USA, it shows that one's work can influence the disposition effect behavior bias. Investors who work in non-professional fields will tend to have a more biased disposition effect behavior.

H4b: Occupation has a negative influence on disposition effect.

Herding bias tends for investors to make investment decisions to follow the crowd (Prosad et al., 2015). According to Kumar and Goyal (2016), herding refers more to investors' tendency to imitate the valuation of an investment with other people. Occupation of investors affects investor behavior bias, one of which is the herding bias (Sarkar and Sahu, 2018). Investors who work in the financial sector do not have a herding bias because they have sufficient investment understanding and do not follow other people.

H4c: Occupation has a negative influence on herding bias.

Thaler (1999) classified it as mental accounting and defined it as a set of cognitive operations used by individuals or households to organize, evaluate, and track their financial activities. Mental accounting is based on the assumption that people make "irrational" economic decisions because of the way they designed their schemes related to money and consumption. Baker et al. (2018) examined that the type of work affected mental accounting. Investors who do not work or retire from their jobs will be vulnerable or lack mental accounting. Mental accounting is influence by an investor's knowledge and understanding of finances (Shefrin and Statman, 1985). Investors who work in finance will tend to have an accounting mentality because they have more knowledge and understanding of finances.

H4d: Occupation has a positive influence on mental accounting.

According to Pompian (2006), this bias tends to be where investors take an investment decision because of excessive confidence in predictions and information. Investors have unwarranted beliefs in terms of intelligence, abilities, and judgment. Tekçe et al. (2016) showed that investors with high-income levels have better self-control and a higher level of confidence in the ability to choose stocks to invest.

H5a: Income level has a positive effect on overconfidence bias.

Fogel and Berry (2006) stated that the disposition effect shows investors want to avoid regret or risk because the decisions taken are the wrong decisions. Investors with high income show a low disposition effect because they tend to increase sales of losing shares and reduce profitable 
stock sales. Based on Dhar and Zhu's (2006) research, it is observed that investors with low income tend to be risk-averse when they have a loss experience.

$\mathrm{H} 5 \mathrm{~b}$ : Income level has a negative effect on disposition effect.

Fernandez et al. (2011) stated that there is an interdependent relationship between available information and group behavior. If investors find uncertain information, investors will imitate decisions with other people or groups. Shusha and Touny (2016) conducted a study that investors with lower middle income tend to have less herding bias. Investors with lower middle income tend to make decisions with accurate considerations and have a high sense of responsibility for the investments made because they feel that there is little capital to invest, so they need to be careful.

$\mathrm{H} 5 \mathrm{c}$ : Income level has a positive effect on herding bias.

Income has a positive correlation to mental accounting (Muehlbacher \& Kirchler, 2019). Sarkar and Sahu (2018) also observed that investors who have high annual income levels tend to show mental accounting bias. High-income investors have more money than low-income investors, and they efficiently allocate their additional investment.

H5d: Income level has a positive effect on mental accounting.

Barber and Odean (2000) found that investors who show excessive self-confidence lead to poor performance and excessive trading. According to Hirshleifer et al. (1998), investors will tend to ignore signals about information and only follow their self-confidence. According to Baker et al. (2018), investors who have a lot of investment experience tend to be more confident than investors who have investment experience under two years. As in previous findings (Barber and Odean, 2001; Bhandari and Deaves, 2006; Lin, 2011; Kumar and Goyal, 2016), investment experience is related to investor confidence.

H6a: Investment experience has a positive influence on overconfidence bias.

Kaustia (2010) stated that disposition effect is a phenomenon where investors tend to realize or sell profits and are reluctant to lose by holding bad stocks. According to Chen et al. (2007), investors who have a more vast investment experience tend to have a lower disposition effect. Investors with experience in investing may have learned to be more rational. Investors can learn from previous experience failures and are less likely to hold on to a losing portfolio for long. H6b: Investment experience has a negative influence on disposition effect.

According to Prosad et al. (2015), investors tend to be herding bias when they have minimal investment experience, less than one year. Minimal investment experience will tend not to be based on personal information but tends to seek information and recommendations from other parties. H6c: Investment experience has a negative influence on herding bias.

Thaler (1999) viewed that mental accounting is a bias that showed investors to regulate, evaluate, and track financial activities. According to Thaler (2003), mental accounting consists of three elements: Photographing how the results of decisions are made and evaluated; Grouping into several accounts of each activity; and, the frequency of each account being evaluated. Investors with more experience are less likely to have a mental accounting bias than those with less investment experience (Baker et al., 2018). Experienced investors are more likely to learn from failures and will increasingly have the ability to diversify their portfolios appropriately.

H6d: Investment experience has a negative influence on mental accounting.

From the above hypothesis formation, a research model was developed, as shown in Figure 1. 


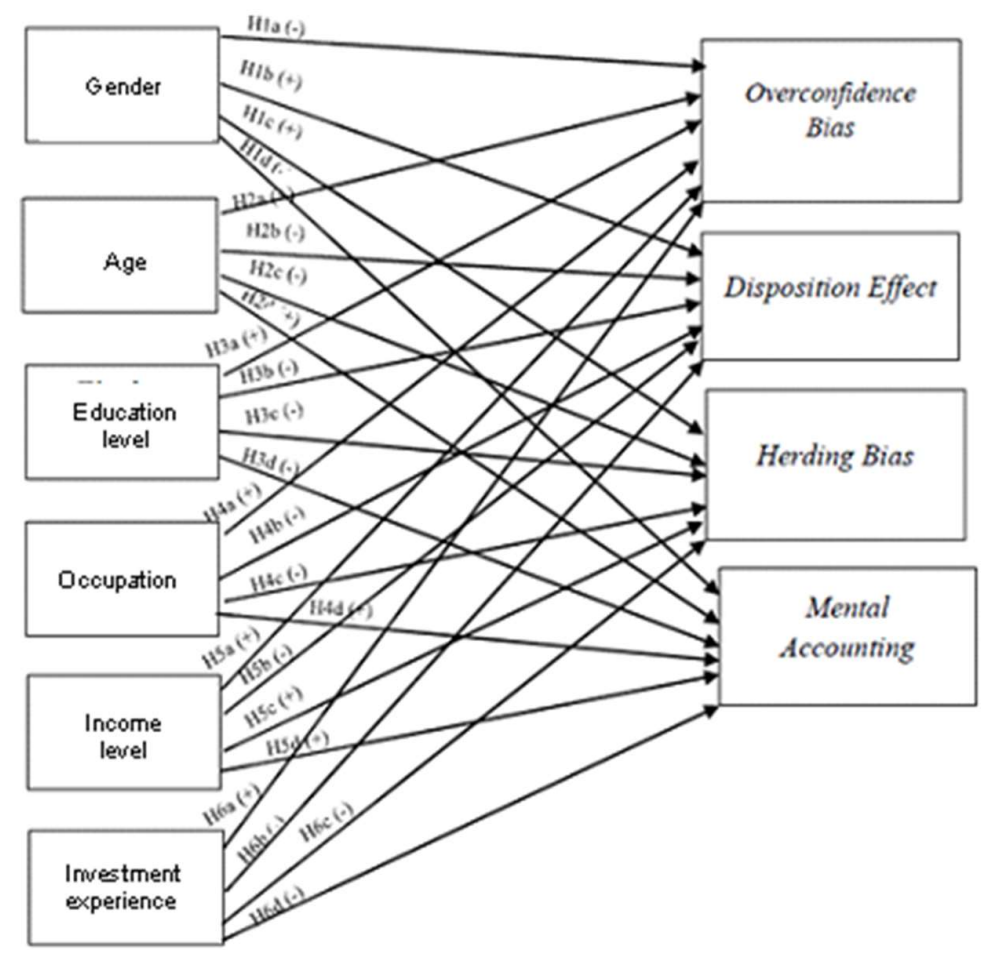

Figure 1. Research Model

\section{Research Methods}

This research is a type of basic research that aimed to identify, explain, and predict natural and social phenomena. Based on the objective, this study was included in causal research because this study explained the effect of independent variables, namely demographic factors, on the dependent variable, namely behavioral biases. Based on the approach, this research was included as quantitative research because it involved quantitative data in processing data which was used as information and distributing questionnaires to respondents to obtain data. The data processing used SEM (structural equation modeling) analysis method.

Based on the analysis method and the research hypothesis, the variables used in this study consisted of four dependent variables and six independent variables. The dependent variable was investor behavioral biases, which consisted of 4 forms, namely overconfidence, disposition effect, herding, and mental accounting. Simultaneously, the independent variables were demographic factors inherent in investors such as gender, age, education level, occupation, income level, and investment experience.

This study used primary data, which was obtained directly from the source. Sources of research data were collected from distributing questionnaires such as research conducted by Baker et al. (2018) which was used as a reference in this research. The questionnaire will distribute to investors who invest in stocks listed on the IDX. Meanwhile, the measurement levels used in this study were nominal and ordinal. The target populations in this study were all investors who have invested in stocks listed on the IDX. The total respondents used in the study were 152 respondents.

\section{Results and Discussion}

This study used data from the distribution of questionnaires as many as 152 respondents. Each variable's indicator was reliable because it had a Cronbach Alpha value> 0.6 (quite reliable). All 152 respondents' data testing for the good fit index. The model fit test was conducted in two models, 
namely measurement models and structural models. The measurement model was done by connecting the dependent variable, namely investor behavior bias with several indicators in it.

Table 1 shows the results of the fit model test for the measurement model; 6 indicators had good fit information or met the criteria, namely Chi-square, RMSEA, AGFI, CMIN / DF, TLI, and CFI. One indicator met the marginal fit criteria, namely GFI, while the measurement model fit could be said to include meeting the good fit criteria.

Table 1. Fit Measurement Model Test Results

\begin{tabular}{|c|c|c|c|c|c|c|}
\hline No. & Indicators & \multicolumn{3}{|c|}{ Criteria } & Result & Note \\
\hline 1 & Chisquare & \multicolumn{3}{|c|}{ Small expected } & 53.27 & Good fit \\
\hline 2 & RMSEA & \multicolumn{3}{|c|}{ RMSEA $\leq 0.08$} & 0.000 & Good fit \\
\hline 3 & GFI & \multicolumn{3}{|c|}{$\mathrm{GFI} \geq 0.90$} & 0.954 & Marginal fit \\
\hline 4 & AGFI & \multicolumn{3}{|c|}{$\mathrm{AGFI} \geq 0.90$} & 0.934 & Good fit \\
\hline 5 & CMIN/DF & \multicolumn{3}{|c|}{$\mathrm{CMIN} / \mathrm{DF} \leq 2$} & 0.635 & Good fit \\
\hline 6 & TLI & \multicolumn{3}{|c|}{ TLI $\geq 0 . \overline{90}$} & 1.077 & Good fit \\
\hline 7 & CFI & \multicolumn{3}{|c|}{$\mathrm{CFI} \geq 0.90$} & 1.000 & Good fit \\
\hline \multirow{8}{*}{8} & \multirow{8}{*}{$\begin{array}{l}\text { Measurement model } \\
\text { fit }\end{array}$} & \multirow{4}{*}{$\mathrm{CR}$} & \multirow{4}{*}{$C R \geq 0.70$} & Overconfidence & 0.859 & Good fit \\
\hline & & & & Disposition effect & 0.786 & Good fit \\
\hline & & & & Herding & 0.763 & Good fit \\
\hline & & & & Mental Accounting & 0.681 & Marginal fit \\
\hline & & \multirow{4}{*}{ AVE } & \multirow{4}{*}{$\begin{array}{c}\text { AVE } \geq \\
0.50\end{array}$} & Overconfidence & 0.759 & Good fit \\
\hline & & & & Disposition effect & 0.518 & Good fit \\
\hline & & & & Herding & 0.548 & Good fit \\
\hline & & & & Mental Accounting & 0.470 & Marginal fit \\
\hline
\end{tabular}

The test continues with the second model, namely the structural model. In the structural model, the dependent variable, namely overconfidence, disposition effect, herding, and mental accounting, will be linked to independent variables, namely demographic characteristics such as age, gender, education level, occupation, income level, and investment experience to see the effect of these two variables.

Table 2. Result of Fit Structural Model Test

\begin{tabular}{|c|c|c|c|c|c|c|}
\hline No. & Indicators & \multicolumn{3}{|c|}{ Criteria } & Result & Note \\
\hline 1 & Chisquare & \multicolumn{3}{|c|}{ Small expected } & 234.071 & Good fit \\
\hline 2 & RMSEA & \multicolumn{3}{|c|}{ RMSEA $\leq 0.08$} & 0.049 & Good fit \\
\hline 3 & GFI & \multicolumn{3}{|c|}{$\mathrm{GFI} \geq \overline{0} .90$} & 0.869 & Marginal fit \\
\hline 4 & AGFI & \multicolumn{3}{|c|}{$\mathrm{AGFI} \geq 0.90$} & 0.923 & Good fit \\
\hline 5 & CMIN/DF & \multicolumn{3}{|c|}{$\mathrm{CMIN} / \overline{D F} \leq 2$} & 1.369 & Good fit \\
\hline 6 & TLI & \multicolumn{3}{|c|}{ TLI $\geq 0 . \overline{90}$} & 0.879 & Marginal fit \\
\hline 7 & $\mathrm{CFI}$ & \multicolumn{3}{|c|}{$\mathrm{CFI} \geq 0.90$} & 0.901 & Good fit \\
\hline \multirow{8}{*}{8} & \multirow{8}{*}{$\begin{array}{l}\text { Measurement model } \\
\text { fit }\end{array}$} & \multirow{4}{*}{ CR } & \multirow{4}{*}{$C R \geq 0.70$} & Overconfidence & 0.861 & Good fit \\
\hline & & & & Disposition effect & 0.688 & Good fit \\
\hline & & & & Herding & 0.770 & Good fit \\
\hline & & & & Mental Accounting & 0.682 & Marginal fit \\
\hline & & \multirow{4}{*}{ AVE } & \multirow{4}{*}{$\begin{array}{c}\text { AVE } \geq \\
0.50\end{array}$} & Overconfidence & 0.763 & Good fit \\
\hline & & & & Disposition effect & 0.522 & Good fit \\
\hline & & & & Herding & 0.570 & Good fit \\
\hline & & & & Mental Accounting & 0.473 & Marginal fit \\
\hline
\end{tabular}

Table 2 shows the fit model test results for the structural model; four indicators had good fit information or met the criteria, namely Chi-square, RMSEA, CMIN / DF, and CFI. Two indicators also met the marginal fit criteria, namely GFI and TLI, while the measurement model fit could be 
said to meet the good fit criteria. Fulfillment of the criteria for a good fit index was at least 3 to 4 indicators that met the criteria. In the two models' test results, the measurement model showed that six indicators met the criteria for a good fit and one indicator that met the marginal fit criteria. The structural model showed that four indicators met the criteria for good fit and two indicators that met the criteria for marginal fit; this showed that this research was good and could continue to conduct hypothesis testing.

Hypothesis testing tried to see the effect of investors' demographic characteristics on the behavioral bias-this test used AMOS 22.0 software, which tested 24 hypotheses in this study.

Table 3. Result of Fit Structural Model Test

\begin{tabular}{lllll}
\hline & & Estimate & $\mathrm{p}$ & Hipothesis \\
\hline H1a & Gender to overconfidence & -0.04 & 0.708 & Negative \\
H1b & Gender to disposition effect & 0.85 & 0.592 & Positive \\
H1c & Gender to herding & -0.113 & 0.513 & Positive \\
H1d & Gender to mental accounting & -0.14 & 0.468 & Negative \\
H2a & Age to overconfidence & -0.122 & 0.156 & Positive \\
H2b & Age to disposition effect & 0.257 & $0.057^{* *}$ & Negative \\
H2c & Age to herding & -0.296 & $0.025^{*}$ & Negative \\
H2d & Age to mental accounting & -0.009 & 0.952 & Positive \\
H3a & Education to overconfidence & -0.016 & 0.547 & Positive \\
H3b & Education to disposition effect & -0.059 & 0.635 & Negative \\
H3c & Education to herding & 0.133 & 0.303 & Negative \\
H3d & Education to mental accounting & -0.122 & 0.453 & Negative \\
H4a & Occupation to overconfidence & 0.039 & 0.707 & Positive \\
H4b & Occupation to disposition effect & -0.097 & 0.534 & Negative \\
H4c & Occupation to herding & -0.280 & $0.085 * *$ & Negative \\
H4d & Occupation to mental accounting & 0.148 & 0.422 & Positive \\
H5a & Income to overconfidence & 0.059 & 0.452 & Positive \\
H5b & Income to disposition effect & -0.308 & $0.017 *$ & Negative \\
H5c & Income to herding & -0.164 & 0.194 & Positive \\
H5d & Income to mental accounting & 0.292 & $0.044^{*}$ & Positive \\
H6a & Investment experience to overconfidence & 0.442 & $0.000^{* * *}$ & Positive \\
H6b & Investment experience to disposition effect & -0.299 & $0.058^{* *}$ & Negative \\
H6c & Investment experience to herding & 0.135 & 0.277 & Negative \\
H6d & Investment experience to mental accounting & 0.005 & 0.972 & Negative \\
\hline * Significant at 5\% & & & \\
** Significant at 10\% & & & \\
*** Significant at 1\% & & & \\
& & & &
\end{tabular}

Table 3 above shows that of the 24 hypotheses, eight hypotheses had a significant effect, namely the H2b, H2c, H4c, H5b, H5d, H6a, and H6b hypotheses. Some were significant at 5\% level, such as the H2c, H5c, and H5d hypotheses. Some were significant at $10 \%$ level, such as H2b, $\mathrm{H} 4 \mathrm{c}$, and $\mathrm{H} 6 \mathrm{~b}$, and one was significant at 1\%, H6a. This research found that other hypotheses had no significant effect.

Age to the disposition effect had a significant positive relationship, which showed that the older the investor is, the more biased the disposition effect followed by the findings of Prosad et al. (2015) and Chen et al. (2007). Prosad et al. (2015) found that a disposition effect bias exists in middle-aged investors who tend to increase trading activity if they experience success from their past experiences. Older investors will tend to sell profitable stocks faster than losing stocks, and the period to hold those losing stocks will be longer than stocks sold at a profit. Age to herding has a significant negative relationship, which showed that the younger the investor is, the more herding bias is; this result was following the research conducted by Baker et al. (2018), who also found that 
there was a significant adverse effect between age and herding bias. His research proved that older investors are less likely to ask for referrals from others. Younger or novice investors tend to be careful in receiving their returns after discussing their investment decisions with their friends.

Occupation and herding found a significant negative effect, indicating that investors who work related to non-financial related had more herding bias, supported by the research of Sarkar and Sahu (2018). Investors who work not in the financial sector tend to have a minimal understanding of investing. An investor who has a non-financial related job will generally feel unfamiliar with the term stocks, and they are busy working so that investors ultimately tend to follow the recommendations of other investors' decisions.

The level of income and the disposition effect found a significant negative effect. Highincome investors had a low disposition effect; that is, high-income investors will tend to have access to financial advisors such as financial and tax planners because they chose to find services that could benefit them. Therefore, investors with higher income have better knowledge regarding investment (Dhar and Zhu, 2006). Another reason is that investors with high-income levels will have more investment at stake; therefore, investors will find it more useful to take advantage of the financial advisor's services. So it can be said that investors with higher income have better knowledge regarding investment. Therefore, the possibility to show a bias disposition effect is smaller. Income level and mental accounting have a significant positive effect on investors who show higher income levels and have a more diverse investment portfolio than those with lower income. Low-income people will have aspirations to get rich, and they will tend to take risks to put any stock to achieve their goal of getting rich. The higher the income level, the investors will realize the benefits of forming an efficient portfolio (Essayyad and Desai, 2008).

Investment experience and overconfidence bias have a significant positive effect. This result was in line with the research of Baker et al. (2018) and Prosad et al. (2015), who found that investors with more experience will have a higher level of confidence if investors are less experienced. Investors who are more experienced in investing in stocks feel confident because of several things: they feel that they are knowledgeable about the stock market, choose good stocks, and be entirely responsible for their investment performance. Also, there is a significant negative effect of investing experience with the disposition effect. Investors with experience in investing have learned to be more rational. Investors can learn from previous experience failures and are less likely to maintain a losing portfolio for a long time (Chen et al., 2007).

This study also found that gender had no effect on overconfidence, disposition effect, herding, and mental accounting. Currently, women had equal knowledge and education with men so that women's self-confidence increases. Investments in stocks are high-risk investments. Women who choose to invest in stocks are likely to have high self-esteem. Utami and Kartini (2016) showed that there was no significant influence between gender and overconfidence bias because excessive self-confidence appeared unclear or unwarranted and depended on their experience in investing. The results of this study indicated that there is no significant effect of women or men on the disposition effect behavior bias; these results are consistent with the research of Kumar and Goyal (2016) and Banarjee et al. (2018). Currently, investors have a higher educational background than in the past, so that in responding to the advantages or disadvantages of investing, they tend to be more rational and do not involve emotions when making investment decisions (Utami and Kartini, 2016). This study's results indicated that there was no significant effect of men and women on herding bias; these results were consistent with the study of Baker et al. (2018). Herding behavior occurs in someone who prefers to follow other people's decisions due to a lack of self-confidence and other psychological things about their own decisions and was not influenced by the gender of the investor.

This study also found that education had no effect on overconfidence, disposition effect, herding, and mental accounting, along with developing the world of technology and social media, allowing investors from any educational background to learn about investing in the capital market 
their own. The disposition effect is experienced by investors who are looking for pride and avoiding regret. Pride-seeking investors cause investors to sell profitable stocks too quickly. Also, investors who tend to avoid regrets cause investors to hold on to detrimental stocks for too long (Muermann and Volkman, 2006). It can be concluded that the disposition effect was not influenced by the level of investor education but it was influenced by the investor's emotional level and how to respond to the impact of the decisions made. The internet is currently effortless to access so that people can easily connect to various facilities in the digital world. Investors can access investment-related information on the internet and exchange information or follow other investors' recommendations through investment groups on social media. These facts support the results of the study that educational background does not affect herding bias.

\section{Conclusion and Future Research}

From the above discussion, it can be concluded that overconfidence bias was influenced by investing experience. The demographic factors, namely age, income level, and investment experience, could influence disposition effect behavior bias. Age and occupation influenced herding behavior and income levels influenced mental accounting bias. The longer the investor had experience in investing, the more likely they would be overconfidence bias. Increasingly old age, investors who have low income and do not have enough investment experience tended to have a disposition effect. The higher the level of income, the higher the investors will have a more diverse investment portfolio to have a mental accounting tendency.

This research can be useful as a reference for financial advisors, investors, and further research. Financial advisors can provide advice and suggestions related to investment alternatives that are suitable for investors' characteristics. For investors, it can be used as a reference to adjust the investors themselves' characteristics so that they can choose the right investment options. Future research can add insight, understanding, and knowledge about the factors that influence investors' investing in stocks. This study has limitations in terms of the lack of response from respondents and the distribution of questionnaires through social media so that there may be some statements that respondents may not understand and understand. For further research, it is useful for the researcher to use more respondents to avoid data imbalances such as this study. It is advisable not to distribute questionnaires online but rather to meet in person or interview.

\section{References}

Alexander, G.J., Jones, J.D. \& Nigro, P., (1997). Investor Self Selection: Evidence from a Mutual Fund Survey. Managerial and Decision Economics, 18(7), 719-729.

Baker, K. H., Kumar, S. \& Goyal,N. (2018). How financial literacy and demographic variables relate to behavioral biases. Managerial Finance, 45(1), 124- 146.

Banarjee, A., De, A., \& Banyopadhyay, G. (2018). Impact of demographic profile on investor biases in India using olap and anova. The Institute of Cost Accountants of India 43(4), 75-94.

Barber, B.M., \& Odean, T. (2001). Boys will be Boys: Gender, Overconfidence, and Common Stock Investment. The Quarterly Journal of Economics, 116(1), 261- 292.

Bhandari, G., \& Deaves, R. (2006). The demographics of overconfidence. The Journal of Behavioral Finance, $7(1), 5-11$.

Byrne, A., \& Brooks, M. (2008). Behavioral Finance: Theories and Evidence. Research Foundation of CFA Institute Literature Review, 1-26.

Chandra, A., Sanningammanavara, K., \& Nandini, A. S. (2017), Does Individual heterogenity Shape Retail Investor Behaviour?. International Journal of Social Economic. 44, 578-593. DOI: 10.1108/IJSE-04- 2015-0097. 
Chen, G., Kim, K. A., Nofsinger, J. R., \& Rui, O. M. (2007). Trading performance, disposition effect, overconfidence, representativeness bias, and experience of emerging market investors. Journal of Behavioral Decision Making, 20(4), 425-451.

Dhar, R, \& Zhu, N. (2006). Up close and personal: investor sophistication and the disposition effect. Management Science. 52(5), 726-740.

Essayyad, M., \& Desai, K. (2008). Behavioural portfolio formation using mental accounting in emerging markets: the case of Saudi Arabia. International Journal of Monetary Economics and Finance, 1(3), 263. DOI:10.1504/ijmef.2008.020635

Feingold, A. (1994). Gender differences in personality: A meta-analysis. Psychological Bulletin, $116(3), 429$.

Fernandez, B., Garcia-Merino, T., Mayoral, R., Santos, V., \&Vallelado, E. (2011). Herding, information uncertainty and investors'cognitive profile. Qualitative Research in Financial Markets, 3(1), 7-33.

Fogel, S.O., \& Berry, T. 2006. The Disposition Effect and Individual Investor Decision: The Roles of Regret and Counterfactual Alternatives. Journal of Behavioral Finance, 7(2), 107-116.

Furnham, A. 1984. Many side of the coin: The psychology of money usage. Personality and Individual Difference, 5(5), 5019-509.

Goo, Y.J., Chen, D.H., Chang, S.H.S. \& Yeh, C.F. (2010). A study of the disposition effect for individual investors in the Taiwan stock market. Emerging Markets Finance and Trade, 46(1), 108-119.

Hirshleifer, D., Daniel K.D., \& Subrahmanyam, A. 1998. Investor Psychology and Security Market Under and Over Reaction. The Journal of Finance, 56(6), 1839-1885.

Isidore, R., \& Christie, P. (2018). The relationship between the income and behavioural biases. Journal of Economics, Finance and Administrative Science, 24(47), 127-144.

Kaustia, M. (2010). Prospect Theory and the Disposition Effect. Journal of Financial and Quantitative Analysis, 45(3), 791-812.

Kahneman, D. \& Riepe, M.W. (1998). Aspects of investor psychology. Journal of Portfolio Management, 24(4), 52-65.

Kahneman, D., \& Tversky, A. (1979). Prospect theory: An analysis of decision under risk. Econometrica, 47(2), 263-292.

Kumar, S., \& Goyal, N. (2016). Evidence on Rationally Biases in Investment Decision Making. Qualitative Research in financial Market. 8, 270-287.

Lewellen, W.G., Lease, R.C., \& Schlarbaum, G.G. (1977). Patterns of investment strategy and behavior among individual investors. Journal of Business, 50(3), 296-333.

Lin, H.W. (2011). Elucidating rational investment decisions and behavioral biases: Evidence from the Taiwanese stock market. African Journal of Business Management. 5(5): 1630-1641.

Muehlbacher, S., \& Kirchler, E. (2019) Individual Differences in Mental Accounting. Frontiers in Psychology, 10, 2866. DOI: 10.3389/fpsyg.2019.02866

Muermann, A., \& Volkman, J.M. (2006). Regret, Pride, and the Disposition Effect. SSRN Electronic Journal. DOI: $\underline{10.2139 / \mathrm{ssrn} .930675}$

Nair, M. A., \& Yermal, L. (2017). Factors Influencing Herding Behavior among Indian Stock Investors. In 2017 International Conference on Data Management, Analytics, and 
Innovation (ICDMAI), 326-329.

Nofsinger, J., R. (2001). Investment Madness: How psychology affects your investing and what to do about it. Prentice Hall.

Nuriyev, N., \& Azizov, A. (2020). Mental Accounting: The Impact of Human Psychology of Financial Decision. Proceedings $37^{\text {th }}$ International Scientific Conference on Economic and Social Development, 1043-1050.

Pompian, M.M. (2006). Behavioral Finance and Wealth Management: How to Build Optimal Portfolios for Investor Biases. John Wiley and Sons, Inc., Hoboken, NJ.

Prosad, J.M., Kapoor, S., \& Sengupta, J. (2015). Behavioral Biases in Indian Investors: a Survey of Delhi-NCR Region. Qualitative Research in Financial Markets, 7, 230-263.

Sakar, A.K., \& Sahu, T.N. (2018). Investment Behavior: Towards an Individual Centered Financial Policy in Developing Economics. Emerald Publisher.

Shefrin, H. \& Statman, M. (1985). The disposition to sell winners too early and ride losers too long: theory and evidence. The Journal of Finance, 40(3), 777-790.

Shusha, A.A., \& Touny, M.A. (2016). The Attitudinal Determinants of Adopting the Herd Behavior: An Applied Study on the Egyptian Exchange. Journal of Finance and Investment Analysis, 5(1), 5-69.

Utami, L.D., \& Kartini, K. (2016). Faktor Demografis, Personality Traits, dan Overconfidence. Jurnal Siasat Bisnis, 20(2), 181-196.

Tekçe, B., Yılmaz, N., \& Bildik, R. (2016). What factors affect behavioral biases? Evidence from Turkish individual stock investors. Research in International Business and Finance, 37, 515526.

Thaler, R.H. (1999). Mental accounting matters. Journal of Behavioral Decision Making, 12(3), 183206.

Thaler, R.H., \& Shefrin, H. 1981. An Economic Theory of Self Control. Journal of Political Economy, 89(2), 392-406.

Yoong, J., \& Ferreira, V. R. D. M. (2013). Improving financial education effectiveness through behavioural economics: OECD key findings and way forward. OECD Publishing, 1, 19261982. 